\title{
Gill Net Selectivity of Hilsa (Tenualosa ilisha) in the Meghna River Estuary of Bangladesh
}

Md. Mehedi Hasan Pramanik ${ }^{1 *}$, Md. Anisur Rahman ${ }^{1}$, Tayfa Ahmed ${ }^{1}$, Flura ${ }^{1}$, Md. Monjurul Hasan¹, Masud Hossain Khan ${ }^{1}$ and Yahia Mahmud ${ }^{2}$ ${ }^{1}$ Bangladesh Fisheries Research Institute, Riverine Station, Chandpur, Bangladesh ${ }^{2}$ Bangladesh Fisheries Research Institute, Headquarter, Mymensingh, Bangladesh

\begin{abstract}
In this study gill-net selectivity for Tenualosa ilisha in the River Meghna was estimated. Traditional fishing was conducted by using gill-net with $55 \mathrm{~mm}, 65 \mathrm{~mm}$ and $75 \mathrm{~mm}$ mesh-size during August 2016 to October 2016. From the Meghna River estuary, a total of 660 specimens of $T$. ilisha were caught by gill-net during the study period. Mean total lengths were calculated as $24.7 \pm 2.7 \mathrm{~cm}, 31.2 \pm 2.78 \mathrm{~cm}$ and $34.33 \pm 4.69 \mathrm{~cm}$ for $55 \mathrm{~mm}, 65 \mathrm{~mm}$ and $75 \mathrm{~mm}$ mesh sizes gill-net respectively. Selectivity analysis indicated an optimum catch length of $260.50 \mathrm{~mm}$ for the 55 $\mathrm{mm}$ mesh size, $328.36 \mathrm{~mm}$ for the $65 \mathrm{~mm}$ mesh size and $370.99 \mathrm{~mm}$ for the $75 \mathrm{~mm}$ mesh size gill-nets. The catch percentage of Hilsa by $55 \mathrm{~mm}, 65 \mathrm{~mm}$ and $75 \mathrm{~mm}$ mesh size gill-net were $38.78 \%, 39.10 \%$ and $22.12 \%$ respectively. The majority of fishes caught by these three-mesh size gill-net were found to be matured. Therefore, $65 \mathrm{~mm}$ mesh size were suitable for the sustainable fisheries of $T$. ilisha in the River Meghna in Bangladesh.
\end{abstract}

Keywords: Gillnet; Tenualosa ilisha; Hilsa; Meghna River; Bangladesh

\section{Introduction}

Tenualosa ilisha is a commercially important and the national fish of Bangladesh. It's an anadromous clupeid fish species which is a popular food fish in South Asia. According to Department of Fisheries, Bangladesh [1], the total (inland and marine) hilsa production of Bangladesh was estimated 3,87,211 metric ton whereas total (inland and marine) fish production was 36,84,245 metric ton in 2014-2015 fiscal year. Hilsa contributes $10.51 \%$ to the total fish production of Bangladesh. The contribution of Hilsa is $1 \%$ to the national GDP of Bangladesh [2].

T. ilisha is the largest single species fishery in Bangladesh. Hilsa has a wide geographical distribution in Asia from the Persian Gulf to the South China Sea. In Upper Bay of Bengal (BoB), particularly large stocks are found to be sustained by the large river systems.

At present $75 \%$ of the global Hilsa catch is caught from Bangladesh waters, $15 \%$ from Myanmar, 5\% from India, and 5\% from other countries such as Thailand, Iran, Iraq, Kuwait, Malaysia, and Pakistan, Kuwait etc. [3].

At present, the Jatka and matured Hilsa fishes are being caught indiscriminately during downstream migration from Meghna River to seawater in the year round cycle. Increasing population, protein demand, temptation of huge income makes an overfishing of Jatka and adults in the gill net fishery [4-6].

Due to the unplanned and unrestricted fishing method Hilsa production and Hilsa size have shown an unknown questionable effect day by day. So recommended optimum mesh size of gill-net for catching Hilsa can be appropriate steps to stop the indiscriminate exploitation of Jatka and matured Hilsa. The aim of this study was to help the stake holders in taking decisions about the determination of optimum mesh size of gill-net for sustainable Hilsa fishing in Bangladesh inland water bodies.

\section{Materials and Methods}

\section{Study area and study period}

The present study was carried out during August 2016 to October
2016 in the Meghna River estuary of Bangladesh. Different Hilsa fishing grounds were selected for this study such as Ramgoti, Hatia and Monpura [7] (Figures 2).

\section{Sampling}

Approximately 660 adult Hilsa were randomly selected from commercial gillnet catches by Riverine Station (RS) Hilsa Research Team of Bangladesh Fisheries Research Institute (BFRI) with speed boat and research vessel ' $M V$ Rupali Ilish' (Figure 1). The gill net with $55 \mathrm{~mm}, 65 \mathrm{~mm}$ and $75 \mathrm{~mm}$ mesh sizes were used for the fishing. These three mesh sizes were selected for analysis because these are mostly used in commercial fishing in Bangladesh.

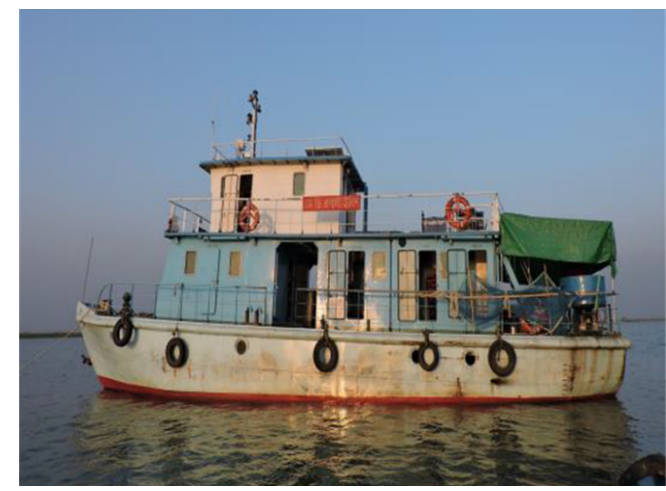

Figure 1: Bangladesh Fisheries Research Institute (BFRI), Riverine Station (RS)'s Research Vessel: 'MV Rupali llish'.

*Corresponding author: Md. Mehedi Hasan Pramanik, Bangladesh Fisherie Research Institute, Riverine Station, Chandpur, Bangladesh, Tel: +8801720618000; E-mail: mehedibfri@gmail.com

Received May 03, 2017; Accepted May 29, 2017; Published May 31, 2017

Citation: Pramanik MMH, Rahman MA, Ahmed T, Flura, Hasan MM, et al. (2017) Gill Net Selectivity of Hilsa (Tenualosa ilisha) in the Meghna River Estuary of Bangladesh. J Aquac Res Development 8: 483. doi: 10.4172/2155-9546.1000483

Copyright: $\odot 2017$ Pramanik MMH, et al. This is an open-access article distributed under the terms of the Creative Commons Attribution License, which permits unrestricted use, distribution, and reproduction in any medium, provided the original author and source are credited. 
Citation: Pramanik MMH, Rahman MA, Ahmed T, Flura, Hasan MM, et al. (2017) Gill Net Selectivity of Hilsa (Tenualosa ilisha) in the Meghna River Estuary of Bangladesh. J Aquac Res Development 8: 483. doi: 10.4172/2155-9546.1000483

Page 2 of 4

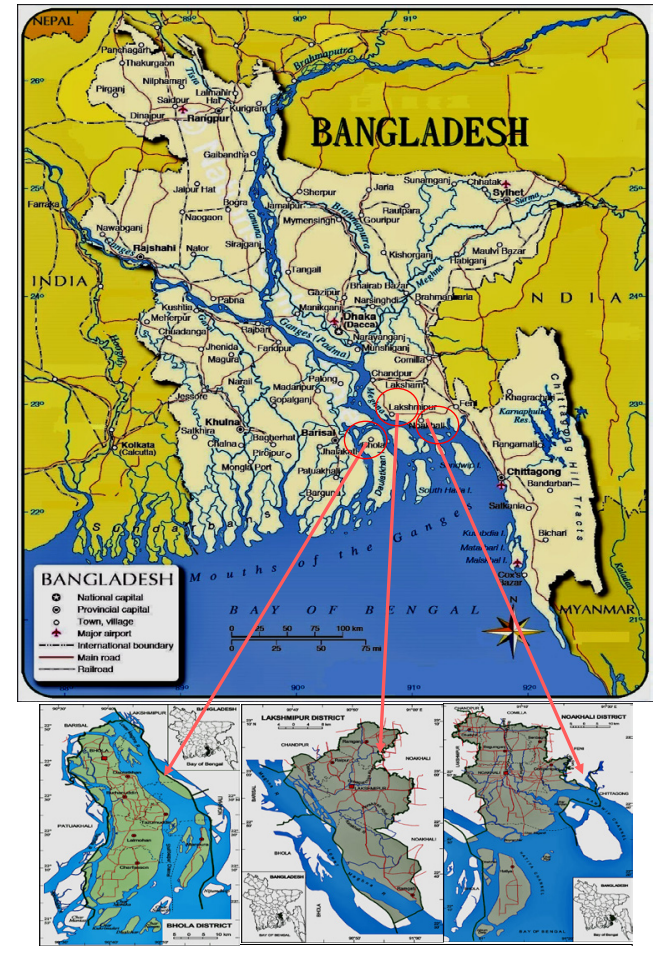

Figure 2: Map showing sampling spots in the Meghna river for collecting Hilsa (Tenualosa ilisha).

\section{Data analysis}

The optimum length $\left(\mathrm{L}_{\mathrm{m}}\right)$ was measured from the data analysis. At first the base line of data_analysis, length frequency of T. ilisha were analyzed. In order to compare and estimate the result, linear regression method was applied. The selectivity parameters were estimated using Holt's model $[8,9]$ by the following formula:

$$
S_{L}=\exp \left[-\left(L-L_{m}\right)^{2} / 2 * s^{2}\right]
$$

Where, $\mathrm{L}_{\mathrm{m}}$ is optimum length for being caught, $\mathrm{S}_{\mathrm{L}}$, fraction (ranged 0 to 10 ), and $S$, the common standard deviation. Input data for this model were the numbers of caught fish by length group for each gear, i.e., $\mathrm{Ca}, \mathrm{Cb}$ and the two used mesh sizes, including ma and $\mathrm{mb}$. The calculation of selectivity parameters was performed as follows:

Step 1: Calculation of log ratios for each length group using $y=\ln (\mathrm{Cb} / \mathrm{Ca})$. Only the lengths where the frequencies overlap were used. In this formula, $\mathrm{Ca}$ is length group caught using the smaller meshed net $(55 \mathrm{~mm})$ and $C b$ is length group caught using the larger meshed net ( $65 \mathrm{~min}$ and $75 \mathrm{~mm}$ ).

Step 2: Performing a regression analysis of the calculated log ratios $[y=\ln (\mathrm{Cb} / \mathrm{Ca})]$ versus the interval midpoint for fish length $(x=L)$, to determine $\alpha$ and $b$ coefficients as following:

$$
y=\ln (\mathrm{Cb} / \mathrm{Ca})=\alpha+b^{*} L
$$

Step 3: The obtained values of $a$ and $b$ along with ma and mb were used to estimate the selection factor $(S F)$ in following formula:

$$
S F=[-2 * a / b *(m a+m b)]
$$

The optimum fish lengths for the small and large mesh size were calculated as following:

$$
L m a=S F * m a \text { and } L m b=S F * m b
$$

Where, Lma is optimum length for the smaller meshed net and $\mathrm{Lmb}$ is optimum length for the larger meshed net. The common standard deviation (s) is determined as following:

$$
s^{2}=\left[-2 * a *(m b-m a) / b^{2} *(m a+m b)\right]=S F *(m b-m a / b)
$$

Step 4: Points on the selection curves are found by inserting values of $L$ :

$$
\begin{aligned}
& S a(L)=\exp \left[-(T L-L m a)^{2} /\left(2 * S^{2}\right)\right] \\
& S b(L)=\exp \left[-(T L-L m b)^{2} /\left(2 * S^{2}\right)\right]
\end{aligned}
$$

Where, $\mathrm{Sa}$ is selection curve for gill-net with $55 \mathrm{~mm}$ mesh size and $S b$, selection curve for gill-net with $65 \mathrm{~mm}$ mesh size.

Step 5: From the obtained data of step 4 and the catches $\mathrm{Ca}(\mathrm{L})$ and $\mathrm{Cb}(\mathrm{L})$, an index of the number in the population is estimated for each mesh size as following:

$$
\begin{aligned}
& N a(L)=C a(L) / S a(L) \\
& N b(L)=C b(L) / S b(L)
\end{aligned}
$$

\section{Results}

Firstly, primary analysis was done. The catch percentage of Hilsa by $55 \mathrm{~mm}, 65 \mathrm{~mm}$ and $75 \mathrm{~mm}$ mesh size gill-net were 38.78\% (256 fish), $39.10 \%$ ( 258 fish), and $22.12 \%$ ( 146 fish) respectively. The majority of fishes caught by the gill-net with three mesh sizes were found to be matured. Total length of the fish ranged from $200 \mathrm{~mm}$ to $360 \mathrm{~mm}$ for $55 \mathrm{~mm}$ mesh size, $240 \mathrm{~mm}$ to $380 \mathrm{~mm}$ for $65 \mathrm{~mm}$ mesh size and 280 $\mathrm{mm}$ to $440 \mathrm{~mm}$ for $75 \mathrm{~mm}$ mesh size gill-net. Mean total lengths were calculated as $24.7 \pm 2.7 \mathrm{~cm}, 31.2 \pm 2.78 \mathrm{~cm}$ and $34.33 \pm 4.69 \mathrm{~cm}$ for 55 $\mathrm{mm}, 65 \mathrm{~mm}$ and $75 \mathrm{~mm}$ mesh sizes gill-net respectively (Table 1).

Secondly, length frequency data were calculated. The distribution at the points designated by $\ln C a(L) / C b(L)$ for three mesh size of gillnets is presented in Figure 3. The regression constants $a$ and $b$ were estimated. For the calculation of selectivity parameters using Holt's method, the data and value of the selectivity parameters are presented

\begin{tabular}{|c|c|c|c|c|c|}
\hline $\begin{array}{c}\text { SI. } \\
\text { No. }\end{array}$ & $\begin{array}{c}\text { Mesh Size } \\
(\mathbf{m m})\end{array}$ & $\begin{array}{c}\text { Fish } \\
\text { No. }\end{array}$ & $\begin{array}{c}\text { Catch } \\
\text { Percentage } \mathbf{( \% )}\end{array}$ & $\begin{array}{c}\text { Total Length } \\
\text { Range }(\mathbf{m m})\end{array}$ & $\begin{array}{c}\text { Mean Total } \\
\text { Length (cm) }\end{array}$ \\
\hline 1 & 55 & 256 & $(38.78 \%)$ & $200-360$ & $24.7 \pm 2.70$ \\
\hline 2 & 65 & 258 & $39.10 \%)$ & $240-380$ & $31.2 \pm 2.78$ \\
\hline 3 & 75 & 146 & $(22.12 \%)$ & $280-440$ & $34.33 \pm 4.69$ \\
\hline
\end{tabular}

Table 1: Catch percentage and mean total lengths of Hilsa by the gill-net with different mesh sizes in the River Meghna of Bangladesh during 2016.

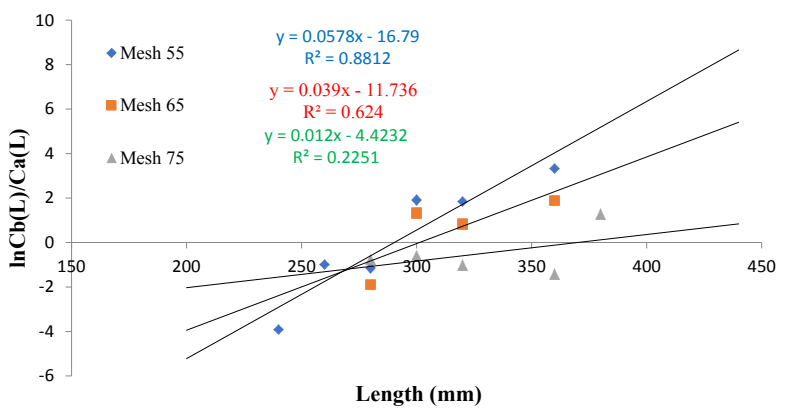

Figure 3: The regression of $\ln (\mathrm{Cb} / \mathrm{Ca})$ on fish length for $T$. ilisha for gill-nets of $55,65 \mathrm{~mm}$ and $75 \mathrm{~mm}$ mesh size from River Meghna in Bangladesh. 


\begin{tabular}{|c|c|c|c|}
\hline \multirow{2}{*}{$\begin{array}{c}\text { Length interval } \\
\text { midpoint } \mathbf{L}(\mathbf{x})\end{array}$} & \multicolumn{3}{|c|}{ Number caught of Hilsa } \\
\cline { 2 - 4 } & $\mathbf{M a}=\mathbf{5 5}$ & $\mathbf{M b}=\mathbf{6 5}$ & $\mathbf{M c}=\mathbf{7 5}$ \\
\hline 200 & $\mathbf{C a} \mathbf{L})$ & $\mathbf{C b} \mathbf{( L )}$ & $\mathbf{C c} \mathbf{( L )}$ \\
\hline 220 & 38 & & \\
\hline 240 & 99 & & \\
\hline 260 & 43 & 16 & \\
\hline 280 & 47 & 15 & 7 \\
\hline 300 & 8 & 54 & 30 \\
\hline 320 & 13 & 83 & 30 \\
\hline 360 & 3 & 83 & 20 \\
\hline 380 & & 5 & 18 \\
\hline 400 & & & 20 \\
\hline 420 & & & 16 \\
\hline 440 & & & 5 \\
\hline 460 & & & \\
\hline Total & $\mathbf{2 5 6}$ & $\mathbf{2 5 8}$ & $\mathbf{1 4 6}$ \\
\hline
\end{tabular}

Table 2: Length-frequency data used for estimating the gill-net selectivity of hilsa (Tenualosa ilisha) in the River Meghna of Bangladesh during 2016.

\begin{tabular}{|c|c|c|c|c|c|c|}
\hline Mesh Size & a & b & SF & s & $\begin{array}{c}\text { Selection } \\
\text { Range }\end{array}$ & $\begin{array}{c}\text { Optimum } \\
\text { Length }(\mathbf{L})\end{array}$ \\
\hline $5.5 \mathrm{~cm}$ & -16.79 & 0.0578 & 4.84 & 38.84 & $254.71-266.28$ & $260.50 \mathrm{~mm}$ \\
\hline $6.5 \mathrm{~cm}$ & -11.73 & 0.039 & 4.63 & 47.58 & $314.69-342.02$ & $328.36 \mathrm{~mm}$ \\
\hline $7.5 \mathrm{~cm}$ & -4.42 & 0.012 & 5.26 & 57.48 & $347.34-394.64$ & $370.99 \mathrm{~mm}$ \\
\hline
\end{tabular}

Table 3: Regression constants ( $a$ and $b$ ), Standard deviation $(s)$, Selectivity factor $(S F)$ and Optimum length $\left(L_{m}\right)$ estimated from the gill-net selectivity studies of Tenualosa ilisha in the River Meghna of Bangladesh during 2016.

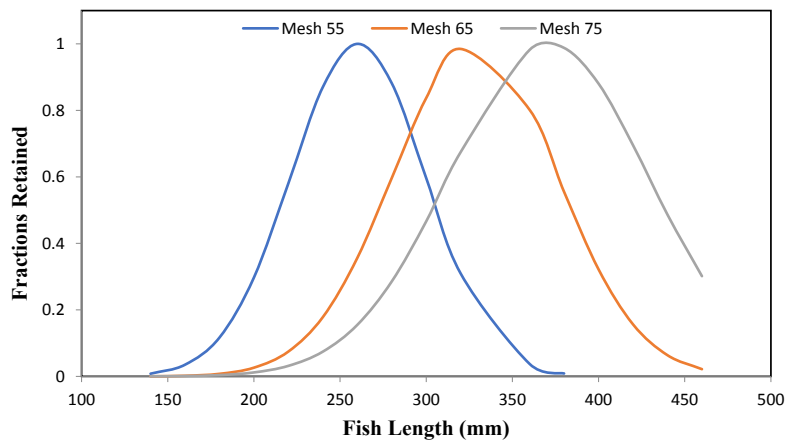

Figure 4: Selectivity curves for $T$. ilisha for gill-nets of $55 \mathrm{~mm}, 65 \mathrm{~mm}$ and $75 \mathrm{~mm}$ mesh size from River Meghna in Bangladesh.

in Table 2. The values of the Selectivity Factor (SF) and Standard Deviation (S) were calculated (Table 3).

The probability of capture against lengths for all mesh sizes showed three different selection ranges and formed a Selectivity curves (Figure 4). The optimum catch lengths of the gill-nets with $55 \mathrm{~mm}, 65 \mathrm{~mm}$ and $75 \mathrm{~mm}$ mesh sizes were calculated as $260.50 \mathrm{~mm}\left(\mathrm{~L}_{\mathrm{m}}\right), 328.36 \mathrm{~mm}\left(\mathrm{~L}_{\mathrm{m}}\right)$, and $370.99 \mathrm{~mm}\left(\mathrm{~L}_{\mathrm{m}}\right)$, respectively (Table 3 ).

\section{Discussion}

Due to the regulation of the mesh size of gill net for recognizing the approximate minimum catch sizes of the target species fishing gear selectivity studies are very important for fisheries management [8,9]. Jatka below $250 \mathrm{~mm}$ size are not allowed to catch in Bangladesh water for sustainable Hilsa production [10]. Therefore, the results indicate that $55 \mathrm{~mm}$ mesh size gill-net for fishing operation should be discouraged for T. ilisha in the River Meghna and its estuary.
Besides, Size at first capture in 1995 to 2003 was $35 \mathrm{~cm}, 30 \mathrm{~cm}, 30.34$ $\mathrm{cm}, 30.25 \mathrm{~cm}, 27.06 \mathrm{~cm}, 22.80 \mathrm{~cm}, 13.12 \mathrm{~cm}, 19.87 \mathrm{~cm}$ and $21.21 \mathrm{~cm}$ respectively presented by BOBLEME [11]. Amin et al. [12] calculated the length at first capture were $29.81 \mathrm{~cm}, 22.80 \mathrm{~cm}$ and $27.06 \mathrm{~cm}$ in the year of 1997, 1998 and 1999 respectively. Rahman and Cowx [13] reported that optimum mean length $\left(\mathrm{L}_{\mathrm{m}}\right)$ at first capture were $329 \mathrm{~mm}$ $(32.9 \mathrm{~cm})$ which was lower than the value $350 \mathrm{~mm}(35.0 \mathrm{~cm})$ of BFRI/ RS Annual Report [14]. Rahman et al. [13] also suggested that less than $325 \mathrm{~mm}$ TL Hilsa must not be captured. In the year of 2013, length at first capture was $26.9 \mathrm{~cm}$ for freshwater and $27.6 \mathrm{~cm}$ for marine water reported by BOBLEME [15]. In the other research work (gillnet selectivity) on T. ilisha, the mesh size wise optimum length were calculated such as $29.05 \mathrm{~cm}$ for mesh size $7.6 \mathrm{~mm}, 39.92 \mathrm{~cm}$ for mesh size $10.2 \mathrm{~mm}, 42.16 \mathrm{~cm}$ for mesh size $11.4 \mathrm{~mm}$ and $53.62 \mathrm{~cm}$ for mesh size $12.7 \mathrm{~mm}$ [16].

Aforementioned all first capture data range of Hilsa are found between $13.2 \mathrm{~cm}$ to $35 \mathrm{~cm}$. As jatka below $25 \mathrm{~cm}$ length size are not allowed for catching, $26 \mathrm{~cm}$ to $35 \mathrm{~cm}$ length size should be taken into consideration regardless of $13 \mathrm{~cm}$ to $25 \mathrm{~cm}$ length size. The length rage found from the present study was $314.69 \mathrm{~mm}$ to $342.02 \mathrm{~mm}$ is within the range of above mentioned length range. Moreover fish at $30 \mathrm{~cm}$ to $35 \mathrm{~cm}$ length range are being caught enormously by the fisherman in Bangladesh [6,17-21]. On the other hand Hilsa above $35 \mathrm{~cm}$ length size are found in lesser amount day by day in the commercial catches. However the use of gill-net with $65 \mathrm{~mm}$ mesh size is appropriate and should be suggested to ensure the sustainability of the Hilsa fisheries resources and will enhance the Hilsa production in Bangladesh.

\section{Conclusion}

Selectivity parameter of T. ilisha was estimated and allowable gillnet mesh size was determined as $65 \mathrm{~mm}$ for sustainable Hilsa fisheries management in the rivers of Bangladesh. Therefore, this conclusion might be an indicator to the optimum fishing range in the rivers and estuary of Bangladesh. Mainly the gill-net selectivity should be used for the Hilsa conservation approach, sustainable Hilsa fishing and implementation of Hilsa Fisheries Management Action Plan (HFMAP) and at least it will help to optimize the fishing standard.

\section{Acknowledgement}

This research work was supported by The United States Agency for International Development (USAID)-funded Enhanced Coastal Fisheries (ECOFISHBD) project of World Fish and the authors are thankful to them.

\section{References}

1. DoF (2016) National Fish Week Compendium (in Bengali), Department of Fisheries. Ministry of Fisheries and Livestock, Bangladesh.

2. DoF (2014) Fishery statistical yearbook of Bangladesh. Department of Fisheries, Ministry of Fisheries and Livestock, Bangladesh.

3. Miah MS (2015) Climatic and anthropogenic factors changings pawning pattern and production zone of Hilsa fishery in the Bay of Bengal. Weather and Climate Extremes 7: 109-115

4. Amin SMN, Rahman MA, Haldar GC, Mazid MA, Milton D (2002) Population dynamics and stock assessment of hilsa shad, Tenualosa ilisha in Bangladesh. Asian Fish Sci 15: 123-128.

5. Amin SMN, Rahman MA, Haldar GC, Mazid MA, Milton DA (2008) Catch per unit effort, exploitation level and production of hilsa shad in Bangladesh. Asian Fish Sci 21: 175-187.

6. Rahman MA, Rahman BMS, Hasan SJ, Flura, Ahmed T, et al. (2013) Impact of eleven days fishing ban in the major spawning grounds of Hilsa (Tenualosa ilisha) (Hamilton) on its breeding success. Bangladesh Research Publications Journal 9: 116-122.

7. Rahman MA (2015) Status of conservation and migration of Hilsa in the 
Citation: Pramanik MMH, Rahman MA, Ahmed T, Flura, Hasan MM, et al. (2017) Gill Net Selectivity of Hilsa (Tenualosa ilisha) in the Meghna River Estuary of Bangladesh. J Aquac Res Development 8: 483. doi: 10.4172/2155-9546.1000483

Meghna River Estuary and its potential of breeding for stock enhancement and aquaculture. ECOFISHBD Project. 1st Year Annual Research Progress Report, BFRI, RS, Chandpur.

8. Sparre P, Venema SC (1998) Introduction to tropical fish stock assessment, Part 2: Manual. FAO Fisheries Technical Paper, Rome, FAO.

9. Sparre P, Ursin E, Venema SC (1989) Introduction to tropical fish stock. Assessment, Part I. Manuel, FAO Fisheries Technical Paper. Rome.

10. MoFL (2013) SRO No. 92-law/2013. Ministry of Fisheries and Livestock. Bangladesh.

11. BOBLME (2011) Report of the Bangladesh hilsa Working Group meeting, 19 May 2011, Dhaka, Bangladesh BOBLME-2011-Ecology-12.

12. Amin SMN, Rahman MA, Haldar GC, Mazid MA, Milton DA, et al. (2004) Stock Assessment and Management of Tenualosa ilisha in Bangladesh. Asian Fisheries Science 17: 51-59.

13. Rahman MJ, Cowx IG, (2008) Population dynamics of Hilsa Shad (Tenualosa ilisha, Clupeidae) in Bangladesh waters. Asian Fish Sci 21: 85-100.

14. BFRI/RS (1994) Bangladesh Fisheries Research Institute, Riverine Station. Hilsa Fisheries Development and Management. Annual Report. BFRI/RS 94.
15. BOBLME (2014) Report of the procedures and methods for continuing assessment of the status of the Hilsa resources. BOBLME-2014-Ecology-06.

16. BOBLME (2014) Report of the procedures and methods for continuing assessment of the status of the Hilsa resources. BOBLME-2014-Ecology-06.

17. Amin SMN, Arshad A, Haldar GC, Shohaimi S, Ara R (2005) Estimation of size frequency distribution, sex ratio and length-weight relationship of Hilsa (Tenualosa ilisha) in the Bangladesh water. Res J Agric \& Biol Sci 1: 61-66.

18. Milton DA (2010) Status of Hilsa (Tenualosa ilisha) management in the Bay of Bengal: An assessment of population risk and data gaps for more effective regional management. Report to FAO. Bay of Bengal Large Marine Ecosystem Project 15: 70.

19. Rahman MA, Emran M, Islam MS (2010) Hilsa Fisheries Management in Bangladesh (BOBPIGO). BOBP-IGO/RC-HF2/5.

20. Rahman MA, Alam MA, Ahmed KKU, Ahmed T, Haldar GC (2008) Assessment of impact of ten days fishing ban in the major spawning grounds of Hilsa (Tenualosa ilisha) Fisher and Bianchi, 1984. Bangladesh J of Fish Res 13: 27-33.

21. Rahman MA, Flura, Ahmed T, Pramanik MMH, Alam MA (2015) Impact of fifteen days fishing ban in the major spawning grounds of Hilsa (Tenualosa ilisha Hamilton 1822) on its spawning success. Res Agric Livest Fish 2: 491-497. 